\title{
IMAGENS ESCRAVAS NAS VISÕES SENHORIAIS: UMA LEITURA DOS CORPOS ESCRAVOS ATRAVÉS DOS ANÚNCIOS DE FUGAS (SÉCULO XIX) ${ }^{1}$
}

\author{
SLAVE IMAGES IN THE VISIONS OF SLAVE MASTERS: \\ A READING OF THE SLAVE BODIES THROUGH SLAVE ESCAPE \\ ANNOUNCEMENTS (19Th CENTURY)
}

\section{IMÁGENES DE ESCLAVOS EN LAS VISIONES DE LOS AMOS DE ESCLAVOS: UNA LECTURA DE LOS CUERPOS ESCLAVOS A TRAVÉS DE ANUNCIOS DE FUGA (SIGLO XIX)}

José Maia Bezerra Neto

\begin{abstract}
Resumo
O presente texto visa tratar das imagens sobre os escravos construídas a partir dos anúncios de fugas publicados na imprensa periódica paraense do século XIX (1840-1888), durante a escravidão, enfocando as leituras dos senhores de escravos sobre o corpo do escravo ou corpos escravos. Enfim, fazendo uso das imagens escravas nas visões senhoriais, neste texto vou tratar da relação entre o corpo do escravo e as marcas da estrutura social: bem como das relações entre corpo e trabalho; corpo, saúde e doença; corpo e imaginário e, por fim, porém não menos importante, a relação entre corpo e identidade. Sendo justamente o corpo ou os corpos cativos ou dos escravos os que serão analisados a partir dos eixos já indicados. Ou seja, a partir de uma análise agregativa e qualitativa de cerca de mil anúncios de fugas escravas, fazendo uma taxonomia destes, se quer conhecer o escravo para além tão-somente da condição de mão-de-obra ou propriedade de alguém, mas como sujeitos portadores de idiossincrasias. Sendo as leituras sobre os corpos e os gestuais escravos, informados pelos anunciantes de suas fugas, os eixos para a compreensão dos cativos como pessoas em sua resiliência, ainda que sujeitos ao domínio senhorial e apesar do tráfico e da escravidão.
\end{abstract}

Palavras-chaves: Escravos. Imagens. Corpo escravo. Anúncios de Fugas. Escravidão.

\begin{abstract}
The present text focuses the images about the slaves built from the escape advertisements published in the 19th century paraense periodical press (1840-1888), during slavery, focusing on the readings of slave masters on the slave body or slave bodies. Finally, making use of slave images in masters visions, in this text I will deal with the relationship between the slave's body and the marks of the social structure: as well as the relationship between body and work; body, health and disease; body and imaginary and, last but not least, the relationship between body and identity. It is precisely the body or the captive bodies or those of the slaves that will be analyzed from the topics already indicated. In other words, from an aggregative and qualitative analysis of about a thousand
\end{abstract}

\footnotetext{
${ }^{1}$ Este artigo faz parte das investigações realizadas pelo autor no campo da história social da escravidão na Amazônia no século XIX.

2 Professor Associado da Faculdade de História/FAHIS e do Programa de Pós-Graduação em História Social da Amazônia/PPHIST do IFCH/ UFPA. Pesquisador do CNPq. Sócio Efetivo do Instituto Histórico e Geográfico do Pará-IHGP. E-mail: jmbn25@gmail.com
} 
advertisements for slave escapes, making a taxonomy of these, one wants to know the slave beyond just the condition of labor or property of someone, but as subjects with idiosyncrasies. As the readings on the bodies and the slave gestures, informed by the advertisers of their escapes, the axes for the understanding of the captives as people in their resilience, although subject to the mastery of the domain and despite the traffic and slavery.

Keywords: Slaves. Images. Slave bodies. Slave escape announcements. Slavery.

\section{Resumen}

El presente texto pretende abordar las imágenes sobre los esclavos construidas a partir de los anuncios de fuga publicados en la prensa periódica paraense del siglo XIX (1840-1888), durante la esclavitud, centrándose en las lecturas de los amos esclavistas sobre el cuerpo de los esclavos o cuerpos de esclavos. De todos modos, haciendo uso de imágenes de esclavos en visiones en las visiones de los amos, en este texto abordaré la relación entre el cuerpo del esclavo y las marcas de la estructura social: así como la relación entre cuerpo y trabajo; cuerpo, salud y enfermedad; cuerpo e imaginario y, por último, pero no menos importante, la relación entre cuerpo e identidad. Es precisamente el cuerpo o los cuerpos cautivos o los de los esclavos los que serán analizados a partir de los ejes ya señalados. En otras palabras, a partir de un análisis agregado y cualitativo de alrededor de mil anuncios de fugas de esclavos, haciendo una taxonomía de estos, se quiere conocer al esclavo más allá de la condición de trabajo o propiedad de alguien, sino como sujetos con idiosincrasias. Como las lecturas sobre los cuerpos y los gestos del esclavo, informados por los anunciantes de sus fugas, los ejes para la comprensión de los esclavos como personas en su resiliencia, aunque sometidos al dominio de los amos y a pesar del tráfico y la esclavitud.

Palabras clave: Esclavos, Imágenes, Cuerpos de esclavos, Anuncios de fugas, Esclavitud.

\section{INTRODUÇÃO}

Reunindo cerca de mil anúncios de fugas de escravos, parte do que foi publicado na imprensa periódica paraense, entre os anos de 1840 e 1880, percebi um conjunto e uma variedade de imagens senhoriais sobre os escravos, afinal quem anuncia são os senhores ou seus prepostos; mas, também, há ricas e variadas imagens (não iconográficas) dos cativos como sujeitos nos "retratos falados" a respeito deles, visando a sua captura. Rebeldes em suas fugas, de certa forma também o foram nos retratos feitos deles se insurgindo nas entrelinhas dos anúncios, aparecendo como sujeitos nas falas dos senhores. Por outro lado, o surgimento da imprensa periódica no Brasil, no século XIX, tornou possível a publicação dos anúncios de fugas escravas nas páginas dos jornais, tornando factível o estudo das fugas e dos fugitivos, revelando as redes de solidariedade e de controle dos senhores e o seu contraponto, no caso as redes cativas em sua resistência ao escravismo. Mas, não somente, existindo outras possibilidades de investigação, comentadas na segunda seção deste texto quando trato dos usos dos anúncios de fugas cativas por parte da historiografia da escravidão, bem como ao longo das demais seçôes.

Fazendo uso das imagens escravas nos retratos senhoriais, trato das relações entre o corpo do escravo e as marcas da estrutura social: corpo e trabalho; corpo, saúde e doença; corpo e imaginário e, por fim, porém não 
menos importante, a relação entre corpo e identidade. Sendo justamente o corpo ou os corpos cativos ou dos escravos os que serão analisados a partir dos eixos já indicados. ${ }^{3}$

\section{OS ANÚNCIOS DE FUGA COMO FONTES DE PESQUISA E A HISTORIOGRAFIA DA ESCRAVIDÃO}

Algumas décadas atrás Gilberto Freyre, analisando os anúncios dos jornais brasileiros, buscou a "interpretação do caráter, do ethos, da formação do brasileiro, do seu passado projetado sobre o futuro em que nos encontramos" (FREYRE, 1979, p. XVI). No livro O Escravo nos Anúncios de Jornais Brasileiros do Século XIX, primeira edição em 1963, reeditado em 1979 e em 2010, Freyre tratou da presença africana no Brasil, a partir dos anúncios de escravos, principalmente nos periódicos Diário de Pernambuco (Recife-PE) e Jornal do Commercio (Rio de Janeiro-RJ), em especial os que tratavam da denúncia e solicitação de captura dos cativos em fuga (FREYRE, 1963; 1979; 2010). Nesta pioneira pesquisa com anúncios de jornais, Freyre almejou "chegar-se a importantes conclusões ou interpretações de caráter antropológico quer psicossomático, quer de todo cultural, à base das descrições oferecidas das figuras, falas e gestos de negros- ou mestiços- à venda e, sobretudo, fugidos: altura, formas de corpo, pés, mãos, cabeças, dentes, modos de falar, gesticulação, doenças" (FREYRE, 1979, p. XIV).

Neste sentido, Freyre extraiu uma gama variada de informações acerca dos escravos, no caso os fugitivos, diagnosticando padrões de caracteres físicos e étnicos indicativos da presença de certas nações africanas no Brasil; ou, então, práticas senhoriais de castigos e sevícias dos cativos; além das doenças, como, por exemplo, o raquitismo. Enfim, estudo pioneiro em seus propósitos, particularmente em relação ao olhar etnográfico dos fugitivos e das fugas escravas no Brasil do século XIX, ainda que compreendesse a fuga como reação quase instintiva de escravos inadaptados ao cativeiro, na medida em que, nas palavras de Freyre, "A benignidade nas relações de senhores com escravos, no Brasil Patriarcal, não é para ser admitida, é claro, senão em termos relativos. Senhor é sempre senhor" (FREYRE, 1979, p. XII).

Ainda que Freyre tenha percebido a importância do estudo da escravidão, particularmente das fugas escravas e dos fugitivos, por meio da pesquisa com os jornais, reunindo cerca de 10 mil anúncios, demonstrandonos o quanto são significativos os anúncios de fugas para a compreensão das relações entre homens livres e cativos, o seu trabalho com jornais continuou durante muito tempo, o único estudo publicado voltado especificamente para análise das fugas escravas no Brasil através do uso em larga escala dos anúncios de escravos fugidos. Só nos anos finais da década de 1980, com o estudo de Luiz Mott (1986; 2008) acerca dos escravos nos anúncios de jornais de Sergipe, o tema voltaria a ter alguma atenção. Havendo antes, é verdade, o estudo de Elisa Graf (1981) sobre imprensa periódica e escravidão no Paraná. Destacando-se nesta época o trabalho de Lilia Moritz Schawrcz (1987)

\footnotetext{
${ }^{3}$ Sobre a história do corpo, ver, por exemplo, Vigarello (2016; 2003); Ceccarelli (2011); Rodrigues (1999); Arasse (2011); Corbin (2011); Courtine (2011); Le Breton (2012); Truong; Le Goff (2006); Del Priori (1995); Del Priori; Amantino (2011). 


\section{Uma leitura dos corpos escravos através dos anúncios de fugas (Século XIX)}

sobre o uso e análise dos jornais em sua pesquisa de mestrado sobre escravos e cidadãos em São Paulo no final do século XIX.

Aparecendo na década de 1990 alguns outros trabalhos, é verdade, como o de Liana Reis (1993), de Flávio Gomes (1996) e deste autor (BEZERRA NETO, 2000). Mas somente nos últimos vinte anos, o estudo das fugas escravas se tornou objeto de investigação de vários pesquisadores, quase sempre trabalhando os anúncios de fugas como fonte de pesquisa, ganhando o tema maior envergadura. ${ }^{4}$ Da mesma forma que, fazendo uso dos anúncios de fugas e de compra, venda e aluguel de escravos, surgiram trabalhos abordando aspectos teóricometodológicos da pesquisa da escravidão com anúncios, ou, ainda, abordando outros aspectos da escravidão tais como o vestuário ${ }^{5}$ ou a saúde escrava, ${ }^{6}$ sendo o corpo do escravo também objeto de investigação.

Enfim, embora alguns desses trabalhos reconhecessem o pioneirismo e a contribuição de Freyre, no tocante ao uso dos anúncios de escravos como fonte para a história, não se pode negar que o reconhecimento dessa contribuição de Freyre tardou a acontecer. Tal fato talvez resulte da forma como a historiografia sobre a escravidão no Brasil circunscreveu a obra de Freyre em torno de sua tese do caráter benigno das relações escravistas no Brasil patriarcal, mesmo sendo esta tese o lastro dos seus diversos estudos. Todavia, como Freyre após Casa Grande \& Senzala não foi só uma mera repetição de si mesmo, aqui comento seu livro $O$ escravo nos anúncios de jornais brasileiros do século XIX, primeiro estudo sistemático dos anúncios abordando o tema das fugas escravas.

Freyre se preocupou em estudar os padrões de fugas escravas e os caracteres físicos e sociais dos fugitivos, porém, duas questões são problemáticas. Primeiro, sua compreensão da natureza das relações entre senhores e escravos a partir do caráter benigno da escravidão brasileira, ainda que, desde ao menos a década de 1960, fosse objeto de críticas por parte de vários estudiosos da escravidão, sendo esta tese criticada e recusada cada vez mais entre os acadêmicos. Mesmo assim, é importante ser frisado minha divergência em relação aos postulados da brandura da escravidão brasileira, uma vez que alguns historiadores e cientistas sociais, em boa medida responsáveis pela crítica a Gilberto Freyre, caracterizaram equivocadamente a historiografia mais recente, que surgiu nos anos finais da década de 1980, como novos discípulos da tese de Gilberto Freyre acerca do caráter brando da escravidão brasileira, o que não faz nenhum sentido. ${ }^{7}$

A segunda questão problemática reside na própria concepção de Freyre sobre a escravidão brasileira, ou seja, a sua compreensão das fugas escravas como que reação quase instintiva dos cativos, uma vez que sujeitos inadaptados. Neste sentido, Freyre afirmava que certos escravos fugiam em busca de outros senhores, abandonando seus perversos proprietários, não sendo a busca de uma liberdade abstrata a razão de suas evasões,

\footnotetext{
${ }^{4}$ Ver, por exemplo, Ferrari (2015); Amantino (2006); Rabelatto (2006; 2007); Neves (2009); Silva (2010); Ailva (2014). Alguns desses trabalhos, inclusive, reconhecendo o pioneirismo de Freyre.

${ }^{5}$ Ver, para além dos trabalhos já citados, por exemplo: Ferrari (2010); Ferreira (2011); Ferrari (2001); Brandão (2004); Souza (2011); Pereira (2013); Maneira (2014); Silva (2019); Sott, (2016); Câmara (2013).

${ }^{6}$ Ver, Por Exemplo, Amantino (2007); Abreu (2014); Alkmim (2006); Jesus (2016); Dias (2011).

${ }^{7}$ Ver, por exemplo, Gorender (1990); e, Queiróz (1999).
} 
até porque de um modo geral as relações entre senhores e cativos seriam marcadas pela benignidade. Então me parece que Freyre não percebia nos anúncios de fugas escravas que os fugitivos seriam capazes de atuarem além da resistência instintiva ao cativeiro, uma vez que ele não via as fugas inseridas no cotidiano de senhores e escravos a partir da cultura do trabalho criada pelos últimos. Mas, na compreensão das fugas escravas como reação causada pela inadaptação do cativo, Freyre não estava sozinho.

$\mathrm{Na}$ época em que Freyre publicou pela primeira vez O Escravo nos Anúncios de Jornais Brasileiros do Século XIX, outros estudiosos da escravidão já criticavam o trabalho de Freyre, particularmente à Casa Grande \& Senzala, no tocante a tese da benignidade da escravidão brasileira, enfatizando a violência do regime escravista e seu correlato: a resistência escrava ao domínio senhorial. Por exemplo, os trabalhos da "Escola Paulista de Sociologia” em torno de Florestan Fernandes (1978), reunindo Octávio Ianni (1988) e Fernando Henrique Cardoso (1977) firmaram marco no pensamento historiográfico brasileiro redimensionando as "verdades" relativas à questão racial e natureza das relações escravistas no Brasil, em suas críticas ao mito da democracia racial e ao caráter benevolente da escravatura brasileira. Entretanto, derrubando aquelas "verdades" tais autores cristalizaram outras, lapidando a tese da brutalização e coisificação dos escravos como decorrência das próprias estruturas de funcionamento do sistema escravocrata. Assim, explicavam as formas violentas de exploração do trabalho escravo e indicavam as razões do processo de exclusão social da população negra na sociedade brasileira, após o término do escravismo. Acontece que, em suas críticas ao caráter brando da escravidão, acabaram substituindo o modelo sociológico proposto por Freyre por outro, no qual, enfatizando o caráter violento do regime escravista, ainda compreendiam a resistência escrava como resultado de sua inadaptação instintiva, uma vez que não compreendiam os cativos como sujeitos capazes de ações autonômicas.

Na década de 1960, no entanto, os estudos da escravidão no Brasil não foram apenas renovados pela sociologia histórica. Em 1966, Emília Viotti da Costa publicou Da Senzala à Colônia. Neste estudo da escravidão nas regiões cafeicultoras do centro-sul do Império, Viotti não se preocupou apenas com a análise das estruturas da economia escravista, mas tratou das condições de vida do escravo e do que denominou como o "protesto do escravizado". Sobre este, Viotti (1999) analisou as fugas escravas percebendo algumas estratégias dos fugitivos visando escapulir ao domínio senhorial, ainda que considerando as evasões escravas incapazes em si mesmas de mudança da ordem estabelecida, só possível a partir do abolicionismo em prática por lideranças não-escravas.

Nesta época, outros autores enfatizando o caráter violento da escravidão, também percebiam a resistência escrava. Em 1972, Clóvis Moura lançou a segunda edição de seu livro Rebeliões da Senzala, antes publicado em 1959. Neste, Moura procurou "restabelecer a verdade dos fatos" no tocante a pretensa passividade do escravo, ao demonstrar como os escravos forjaram formas de luta e de contestação contra a sua condição de propriedade de outro (MOURA, 1972). Desde então, outros investigadores sociais da resistência escrava também percebiam a negação da condição social de cativo: Décio Freitas (1982), José Alípio Goulart (1972), Suely Robles Reis de 


\section{Uma leitura dos corpos escravos através dos anúncios de fugas (Século XIX)}

Queiróz (1977), Luís Luna e Carlos Magno Guimarães (1968). Todavia, consolidando-se na historiografia a percepção do caráter violento da escravidão brasileira concomitantemente ao surgimento de estudos acerca da resistência escrava, pouca atenção foi dada às fugas escravas, sendo o livro de Freyre até então a única pesquisa direcionada ao tema.

As fugas escravas foram tratadas como mais uma entre outras formas de luta dos escravos, apesar de considerada a forma mais usual de resistência dos cativos, enquanto na historiografia sobressaíam as pesquisas relativas aos quilombos e, às vezes, acerca das rebeliões escravas. A pouca relevância atribuída ao estudo das fugas explica-se pela compreensão dos estudiosos da resistência escrava que viam nas fugas apenas a recusa do cativo em continuar servindo ao seu senhor, seja pela sua inadaptação, seja pela busca instintiva da liberdade, sem maiores significados culturais e políticos. Ou seja, compreendendo a fuga como ato mais frequente de negação da escravidão não havia porque se estudar mais amiúde as próprias fugas, uma vez que sua natureza (a negação da ordem escravista) já estava explicada: o escravo fugia porque não queria ser escravo, nada mais.

Somente no final da década de 1980, mais ainda na de 1990 em diante, quando da renovação da historiografia brasileira acerca da escravidão, começou efetivamente a percepção que entre senhores e escravos não havia apenas o conflito aberto, havia também a negociação, portanto, as fugas não seriam apenas a negação da escravidão em busca da liberdade e mesmo que fossem ainda careceriam de estudos mais específicos. Entre os estudos históricos que vieram à tona, ainda que pesem as suas diferenças, é possível perceber de um modo geral a preocupação com a escrita de uma história social da escravidão no Brasil vista de baixo, na qual os escravos deixavam a condição de figurantes das estruturas sociais, situação que até então lhes era destinada, e tornavam-se personagens de suas próprias histórias. Na medida em que apresentavam uma (re)leitura da escravidão na qual os cativos passaram a ser vistos como trabalhadores capazes de protagonismo, desenvolvendo formas de organização social e familiar, sem que fossem compelidos em seus atos e reações unicamente pelo exercício da violência e autoridade senhorial.

Enfim, a história do trabalho no país não começava no período pós-abolição. Portanto, estabelecia a compreensão do protesto escravo ou suas formas de resistência contra a escravidão e o processo de exploração de seu trabalho pelos senhores, tais como as fugas, como parte da história do trabalho e das tradições de lutas dos trabalhadores no Brasil.

Neste contexto, Eduardo Silva fez o seu estudo das fugas escravas no Brasil, ainda que compreendendo as evasões dentro de um modelo explicativo no qual, estabelecendo as chamadas fugas para fora e fugas para dentro, recolocava de certa forma a dicotomia entre liberdade e escravidão (SILVA, 1989, pp. 62-78). De qualquer forma, Silva preocupou-se em compreender importante aspecto da escravidão até então pouco estudado pela historiografia, ainda que considerado pelos historiadores como prática corriqueira no cotidiano das relações entre senhores e escravos, ou seja, as fugas escravas. Silva, ainda que trabalhasse com a ideia de fugas para fora e fugas 
para dentro, em seu esforço de teorização estabeleceu importantes categorias para entender as fugas escravas como algo mais do que só a negação da escravidão pela busca da liberdade ou como reação de certos escravos inadaptados à condição de cativo. Segundo Silva (1989) é possível perceber entre a negociação e o conflito, tanto as fugas-reinvindicatórias quanto as fugas-rompimento, sendo diversas as razões por detrás das evasões dos trabalhadores escravos, desde a saudade dos familiares e o desejo de reencontro com eles, até a luta pelo que consideravam seus direitos, senão a busca da própria liberdade.

Nas décadas finais do século XX, contudo, poucos trabalhos no Brasil ainda tinham se dedicado ao estudo das fugas escravas e dos fugitivos, ainda que anúncios de escravos fugidos existam aos milhares nos jornais brasileiros do século XIX, ou seja, uma fonte privilegiada e importante de forma nenhuma escassa. Os anúncios de escravos fugitivos geralmente trazem o nome do escravo; o nome do senhor; idade estimada do cativo; qualificação; cor; caracterização física do fugitivo; local da fuga; possível paradeiro; data da fuga; data do anúncio; promessa de recompensa ou gratificação. Bem como outras informações, algumas delas eventuais, como nome(s) do(s) antigo(s) senhor(es); procedência ou lugar de origem do escravo; etnia, quando africano; meio de fuga; como fugiu, se em grupo ou só, levando carrego ou não; se houve fugas anteriores; além de possíveis recomendações, nomes de procuradores em outros pontos da província, além de observações sobre vestuário do fugitivo, práticas comportamentais ou relações sociais ou familiares.

Enfim, a partir e através dos anúncios de fugas, para além dos estudos sobre as fugas escravas, é possível tratar de diversos aspectos da escravidão. Um deles diz respeito ao corpo do escravo, ainda que seja uma leitura senhorial sobre o outro, o que também é reveladora de como os senhores e demais segmentos livres compreendiam a figura do escravo, não deixando de serem importantes as informações senhoriais sobre seus escravos, seus corpos e atitudes, afinal não deixavam os senhores ou seus prepostos de ser observadores imediatos e privilegiados dos cativos que então eram retratados, com seus corpos e almas anunciados e devassados.

\section{O CORPO ESCRAVO E AS MARCAS DA ESTRUTURA SOCIAL}

Os anúncios de fugas dizem muito sobre o corpo do escravo e as marcas da estrutura social, a partir das descrições físicas dos corpos cativos, ainda que houvesse anúncios lacônicos a respeito. As marcas da estrutura social dizem respeito às condições e relações de trabalho cadenciadas por políticas de controle social e disciplinamento dos escravos, através do recurso aos meios coercitivos violentos por parte dos senhores ou seus prepostos ou, ainda, aplicados pelas autoridades públicas vigentes em nome da segurança pública, ${ }^{8}$ o que fazia com que nos corpos dos cativos ficassem tatuadas as marcas dos castigos senhoriais. Cativos com sinais de açoites, tal como o cafuz Furtinato, aparentando 41 anos, "cheio de corpo, estatura ordinária, pouca barba, alguma falta de

\footnotetext{
${ }^{8}$ Sobre a questão ver Lara (1988). 
dentes, cabellos bastante frizado", tendo "em hum dos braços huma cicatriz"; que tinha então "pelas costas alguns signaes de pancadas, e foi no fim de anno [de 1850] castigado na cadeia desta cidade [Belém]".

Havendo ainda a cafuza Florencia, 25 anos, "estatura ordinária, cheia de corpo, rosto redondo, olhos vivos", com os "pés grandes e secos", com cicatrizes de vergalho nas costas. Florencia tinha fugido levando roupa preta, "tanto saia como camisa", bem como sua filha Martinianna, 6 para 7 anos, indo fugida na companhia da "preta retinta" Geralda, "18 annos, estatura ordinaria, cheia de corpo, porem não tanto como a outra”, que também tinha "cicatrizes de vergalho nas costas". A preta Aguida quando fugiu foi dito que trazia "signaes de surra no assento". No caso de Roque, segundo seu senhor, teria "signaes de ter sido castigado, mas já a annos". 9

Joaquim, 18 anos, descrito com "muitas titinga na câra", além das titingas (manchas brancas, pano ou sardas) no rosto, tinha então "cicatriz nas costas", indicando muito provavelmente marcas de ter sido em algum momento castigado com açoites. Se há alguma dúvida sobre as cicatrizes nas costas de Joaquim, o mesmo não pode ser dito em relação ao escravo Maximiano ou Maxico, 28 anos, descrito como alto, barbado, com uma pequena cicatriz em uma das pestanas, que carregava "veziveis signaes de cicatrizes nas costas, em ambos os lados lombares, e em menos quantidade no assento, de castigos que lhe fez seu antigo senhor". Nos anúncios de fugas também encontro Florentino, entre 20 e 22 anos, "mulato um pouco escuro, cabellos crespos e ruivos nas pontas, os dentes da frente podres" com as orelhas furadas "dias antes da sua fuga, o que deve apresentar vestigios, cazo não se tanhão tapado", que em fuga costumava dizer chamar-se Antônio Macapá, e que tinha "uma cicatriz de golpe ao longo do pescoço", e também "marcas de surra na bunda", ou seja, havia sido açoitado. Por sua vez, Marcos, que segundo seu senhor era "dado a bebida e muito amigo de reviras" tocando rabeca com o braço esquerdo, podia ser reconhecido por ser "cicatrizado nas nádegas, onde foi surrado". ${ }^{10}$

Marcas de surras com açoites ou chibatas nas costas ou nádegas, no entanto, não eram os únicos marcadores de estrutura social nos corpos dos cativos. O uso de ferros (calcetas, argolas, algemas e correntes) também imprimia marcas do domínio senhorial nos corpos escravos. Assim sendo, Pedro, que não tinha "a cabeça do dedo emediato ao minimo da mão direita", tinha "sobre os calcanhares signal de ferros"; ou Rafael com "o pé grosso do ferro que trazia", são exemplos de escravos que traziam nos corpos as marcas da escravidão, no caso os castigos com uso de ferros, marcações pelas quais podia ser reconhecida sua condição cativa. Disto não tinha dúvidas o senhor do cativo André com "algumas cicatrizes nas pernas, além de outros signaes por onde logo mostra ser escravo", sem ter o trabalho de descrevê-los, pois ficava entendido que se referia a cicatrizes de vergalho ou

\footnotetext{
${ }^{9}$ Ver referências nos jornais: O Planeta (31/05/1851, p. 4; 20/12/1849, p. 4; 31/05/1851, p. 4); O Doutrinário (15/07/1848, p. 4).

${ }^{10}$ Ver referências nos jornais: O Planeta (27/03/1852, p. 3); Treze de Maio (19/06/1846, p. 4); O Correio dos Pobres (22/09/1851, p. 4); O Velho Brado do Amazonas (28/03/1851, p. 4).
} 
chibata, ou então marcas ou aleijões pelo uso de ferros, que imprimiam nos corpos desses sujeitos as marcas da escravidão. ${ }^{11}$

Sinais que traduziam uma identidade visual da condição cativa. Uma vez que devido o uso dos açoites e de ferros, as marcas impressas dolorosamente nos corpos dos trabalhadores escravos constituíam verdadeiros emblemas da condição escrava. Daí que o tenente coronel Anselmo Joaquim da Silva dizia que seu escravo fugido Thomaz tinha um sinal antigo visível "por onde pode ser logo conhecido, o qual he uma grande sicatriz nas cadeiras dos castigos que já teve" (O PUBLICADOR PARAENSE, 22/10/1851, p. 4).

$\mathrm{Na}$ ausência de sinais físicos dos castigos sofridos, outros, é verdade, serviam para a identificação e captura dos escravos fugidos, devendo, no entanto, serem salientes. Assim sendo, Claudino foi descrito com uma acentuada corcunda, esclarecendo o senhor que ele era assim por "geito mesmo do corpo", não por pancada ou castigo sofrido. Francisco ou Chico Tapuio, por sua vez, tinha "um signal por onde facilmente será reconhecido, o qual é ter sempre um olho meio fechado", ainda que sua cor atapuiada o permitisse passar por caboclo livre. Isto é, só seriam identificados como escravos fugidos por que já eram conhecidos como tais ou então denunciados pelos senhores, visto que ser corcunda ou sofrer de pálpebra caída não queria dizer que alguém fosse cativo, mas que tão-somente eram na ocasião os sinais físicos que podiam ajudar em sua captura, ainda mais não sendo os mesmos algo comum. Daí que, Julião da Fonseca Freitas, descrevendo seu escravo fugido, o carpinteiro Anastácio, dizia apenas que ele era alto e sadio, se lamentando que Anastácio não tinha "cicatriz alguma pela qual se possa fazer mais conhecido". ${ }^{12}$

O que já foi dito dos castigos aplicados aos escravos que imprimiam marcas ou sinais distintivos da condição cativa em seus corpos, também pode e deve ser pensado nos termos das relações entre corpo e trabalho, ainda que o recurso à violência seja elemento importante do exercício da autoridade moral dos senhores sobre seus cativos e, portanto, das relações entre corpo e marcas da estrutura social. Isto é, os escravos não eram só passíveis de castigo quando não trabalhavam ou trabalhavam mal, mas quando eram vistos como rebeldes, ainda que a recusa ao trabalho ou a sua sabotagem não estivesse necessariamente dissociada da resistência cativa. Nos anos finais da década de 1860, o antigo líder cabano Eduardo Angelim sabia bem destas coisas, quando anunciando a fuga de seu escravo Raymundo caracterizava-o da seguinte forma: "Signaes carasteristicos do meu heroe, a saber: estatura regular, espigado, cara redonda, falla bem e mente muito, não bebe aguardente quando não a acha, trabalha muito bem no serviço do campo, quando seu senhor ou feitor está atesta do trabalho" (DIÁRIO DO GRAM-PARÁ, 17/07/1867, p.3). Trabalho escravo era, portanto, trabalho feitorizado com recurso aos castigos corporais que imprimiam marcas distintivas da condição cativa desse trabalhador.

\footnotetext{
${ }^{11}$ Ver referências nos jornais: Treze de Maio (25/05/1844, p. 3); Treze de Maio (23/04/1845, p. 4).

${ }^{12}$ Ver referências nos jornais: Treze de Maio (22/01/1845, pp. 3-4); O Planeta (23/07/1850, p. 3; 17/08/1850, p. 8). 


\section{AS RELAÇÕES ENTRE CORPO E TRABALHO}

As relações entre corpo e trabalho iam além das marcas deixadas pelos castigos visando punir serviços mal feitos, faltas ou, ainda, adestrar e dar o ritmo de produção ou execução das atividades laborais. Podem ser observadas nas mãos calejadas pelo trabalho manual, nas palmas grossas dos pés que desconheciam sapatos, no corpo definido ou redefinido, ou ainda, quase sempre, deformado pelas jornadas de laboro. Embora seja verdade, nem sempre os anúncios falem disto em suas descrições físicas dos cativos em fuga.

Os anunciantes só tratavam das marcas causadas nos corpos cativos pelas atividades laborais quando podiam ser sinais de reconhecimento do fugitivo. Assim, o escravo Maximiano, já citado antes, era "quebrado de uma virilha, cuja hérnia se faz volumosa quando desce”. Outro já citado, que também sofria de hérnia era Florentino, "quebrado de huma das virilhas". O africano e calafate Joaquim (nação Cabundá), "estatura regular", "cabeçudo", "dentes limados", "pouca barba", também era "quebrado e muito disforme do escroto", possuindo ainda "um signal de queimadura n'hum dos braços", sendo "aleijado n'hum dos dedos da mão" (TREZE DE MAIO, 15/07/1840, p. 4.).

Sinais e deformações corporais que bem podiam ter sido causadas pelas atividades laborais. Havendo ainda certo africano de Angola, chamado Domingos que, "cheio de corpo", "altura regular", com "hum signal na garganta" e "muito espivitado no fallar", era "rendido das virilhas". O angolano Domingos havia fugido na noite de 11 para 12 de fevereiro de 1845 junto com o cativo Pedro, levando suas caixas de roupa. Reconduzido ao domínio senhorial, mais uma vez fugiu em 11 de novembro de 1845, dizendo quando fugia que era forro. Novamente apanhado, não desistiu, fugindo em 28 de março de 1846, ainda que usando "ferros no pé e no pescoço", bem como lhe faltando a "orelha direita", punições aplicadas no fujão Domingos, visando quebrar-lhe inutilmente seu inconformismo. ${ }^{13}$

O sapateiro Joaquim, cor "fula", "alto", "magro", "orelhas grandes" e todos os "dentes podres", ainda "moleque", porque tinha "pouco mais ou menos 18 annos", por sua vez, também era "quebrado nas virilhas". O maranhense Noberto, sapateiro, preto "mui fula", com "estatura regular", "cheio de corpo", "bastante barbado na ponta do queixo", era igualmente "rendido de uma virilha". O oficial de calafate Paulino Francisco, preto "retinto", "baixo", "pouca barba", também era outro "rendido dos escrotos". ${ }^{14}$ Sofriam então esses cativos de hérnia inguinal que podiam ser congênitas ou causadas por esforços físicos no trabalho, crendo ser a última hipótese a mais comum, chamando atenção que alguns desses cativos não tinham idade avançada, sendo novos, uma vez que iniciavam suas vidas no trabalho ainda cedo. Até porque muitas vezes cabia aos escravos de ganho ou de aluguel, nas cidades, ou de eito, no campo, o carregamento de toda e qualquer carga, inclusive pesadas, como parte de seu

\footnotetext{
${ }^{13}$ Ver as diversas fugas do Africano Domingos nos seguintes anúncios publicados no jornal Treze de Maio (12/02/1845, p. 4; $12 / 11 / 1845$, p. $4 ; 28 / 03 / 1846$, p. 3$)$.

${ }^{14}$ Ver as referências nos jornais: O Planeta (4/11/1852, P. 4); Treze de Maio (15/08/1840, P. 4); Diário do Gram-Párá (9/11/ 1867, P. 4).
} 


\section{Uma leitura dos corpos escravos através dos anúncios de fugas (Sécullo XIX)}

trabalho braçal. Enfim, os anúncios permitem relacionar a qualificação para determinados trabalhos ou ofícios e o estado ou condições de saúde do cativo em fuga, demonstrando a relação entre possíveis deformidades ou patologias corporais e o trabalho.

No bojo das condições de trabalho, o próprio ritmo monótono e repetitivo de certas atividades físicas frequentemente causava uma ou várias deformações nos corpos dos trabalhadores escravos. Desta forma, alguns senhores prolixos possuíam o cuidado de informar nos anúncios de fuga que certos aleijões nem sempre provinham dos pesados e constantes exercícios impostos aos escravos em suas labutas diárias. Antônio Rodrigues dos Santos Almeida, por exemplo, quando descrevia Claudino afirmava ser seu escravo "muito corcundo, geito mesmo do corpo" (O PLANETA, 23/07/1850, P. 3).

Enfim, as marcas de trabalho aparecem nos corpos cativos, revelando-nos o peso das atividades laborais que, embora não exclusivas dos trabalhadores escravos, sendo partilhada por libertos e pobres livres, nos corpos dos escravos imprimiam mais um sinal identificador de sua condição cativa, como sujeitos integrantes das classes trabalhadoras. O mestre pedreiro Gregório, por exemplo, descrito como "baixo", "nariz afilado" e "andar tezo", trazia "um golpe de machado no pé direito". Em "um dos pés uma cicatriz produzida por um golpe de machado" também tinha Venâncio, 30 e 35 anos, possível trabalhador rural fugido do Sítio Arassy, na Baia do Sol, ilha do Mosqueiro, distrito de Belém, sendo este o único sinal pelo qual poderia ser reconhecido, além da "Cor preta" e "altura regular" informada por seu senhor. Fidelis, que fugiu da fazenda Curuçambá, "25 annos", "alto e bem feito", "olhos hum tanto avermelhados", também tinha "no pé esquerdo hum grande golpe de machado; e nas nádegas alguns signaes de castigo". Morador no Rio Moju, o "preto crioulo" Antonio, com "algumas titingas na cara, côr fula, altura regular, cheio de corpo, cabelo duro", com "26 annos" e que gostava de "andar limpo", também podia ser reconhecido em sua fuga por "um golpe de machado em hum dos braços". O pedreiro João Baptista tinha o "dedo indis [indicador] da mão esquerda defeituosa, e achatada em conseqüência de uma pancada de martello que sofreo". ${ }^{15}$

As marcas das atividades laborais que, então, bem podiam definir a silhueta de alguns corpos escravos, daí que alguns cativos eram descritos como portando bonitas figuras ou corpos bem formados, também machucavam e deformavam ou, ainda, mutilavam os corpos escravos, muitas vezes devido ao ritmo pesado e repetitivos dos trabalhos realizados, consequentemente acarretando problemas de saúde.

\section{CORPO, SAÚDE E DOENÇA}

Nos tópicos anteriores já disse alguma coisa sobre essa relação, ainda que implicitamente. As marcas, sinais ou cicatrizes produzidas ou deixadas pelas diversas patologias congênitas ou adquiridas pelos trabalhadores

${ }^{15}$ Ver as referências nos jornais: Treze de Maio (21/02/1846, P. 4); Jornal do Pará (15/09/1868, P. 3); Treze de Maio (13/05/1854, P. 4; 9/06/1855, P. 4; 21/05/1845, P. 4). 


\section{Uma leitura dos corpos escravos através dos anúncios de fugas (Sécullo XIX)}

cativos, ainda que não fossem exclusivas da condição escrava, tornavam-se referências gravadas em seus corpos favorecendo seu reconhecimento. D’algumas delas já falei, particularmente das hérnias. Mas havia outras. Vários são os cativos que traziam marcas ou sinais de bexigas (varíolas) em seus corpos, pelo que podiam ser identificados, tais como o citado cafuzo Roque com "cicatriz de bexigas no peito do lado direito". Ou, ainda, Jesuíno com "rosto comprido e bastante estragado das bexigas como todo o corpo". Ou José, "com uma cicatriz na testa e outra no braço esquerdo, resultado de uma facada", que tinha "rosto bexigoso". ${ }^{16}$

A forma de andar era uma das maneiras de identificação dos fugitivos. Os anúncios trazem informações sobre o referido gestual, o qual, para além de uma dada inclinação ou jeito de ser de cada um. Traduzia também patologias sofridas pelos cativos, congênitas ou adquiridas, entre elas aquelas oriundas por castigos físicos, acidentes ou cargas de trabalho, condições de saúde e alimentação. O carapina Thomaz, que mudava seu nome para José Thomaz, 22 anos, "estatura baixa", "cara redonda", "com huma cicatriz em cima de cada huma das sombracelha proveniente de abcessos que teve na primeira infância" era "bastante cambaio do pé direito, cuja ponta extremamente mette para dentro quando anda". Roberto, "bastante fulo", "estatura regular", "gago", também quando andava deitava "as pontas dos pés para dentro". Manoel Raimundo, "18 annos pouco mais ou menos", "cabelo corredio", com "cicatriz por cima da sobrancelha", "fala grosso", "beiços um pouco delgado" e "baixo", era "cambado das pernas", ou seja, tinha pernas tortas ou era coxo. ${ }^{17}$

Outros cativos eram acometidos por problemas de saúde causados por andarem descalços: Francisco Alfaiate, 40 e tantos anos, ainda que "bem nutrido", tinha "sicatrizes de ser surrado" e pisava "como se tivesse os pez cheio de bixos". Boaventura tinha "cicatrizes d'azorrague antiga nas pás [e] alguns signais de bixos nos pés, e estes [eram] abertos para fora". Justino, "com cicatriz de golpe no lado inferior da orelha direita", era "um tanto bixento nos pés". Também doenças de pele não tratadas ficavam crônicas, sendo sinais nos corpos dos fugitivos: José tinha "umas chagas na perna esquerda". Francisco tinha "nas costas duas grandes maltas de empige". Mamede tinha "hum signal grande de empigem nas costas". Manoel tinha no rosto "nodôas de impingens". ${ }^{18}$

Já o escravo de aluguel Claudino, já citado por conta de sua corcunda, quando andava tinha "as pernas tropicas de caroara que teve", isto é, tremedeira por medo ou cansaço. Patologias psicossomáticas, para além da caroara, como a geofagia que acometia o "cafuz claro" Cicilio, 10 a 12 anos, "reputado até então por pessôa livre", anunciado como escravo fugido, com "rosto largo e cabelludo [que] as vezes torna[va]-se amarello pelo vício que tem de comer terra [e] quasi constantemente tem o beiço inferior branco". A gagueira também era sinal de identificação dos escravos. Roberto, já citado antes, era descrito como "gago"; Raimundo, 18 a 20 anos, com

\footnotetext{
${ }^{16}$ Ver referências nos jornais: O Doutrinário (15/06/1848, P. 4); O Publicador Paraense (28/06/1852, P. 4); Treze de Maio, 14/05/1844, P. 4.

${ }^{17}$ Ver Referências nos Jornais: O Velho Brado do Amazonas (26/03/1852, P. 4); O Planeta (29/09/1851, p. 4; 18/04/1850, p. 4).

${ }^{18}$ Ver referências nos jornais: Treze de Maio (7/06/1845, p. 3); O Publicador Paraense (31/12/1850, p. 4; 24/10/1849, p. 4); Treze de Maio (3/06/1846, p. 4; 29/08/1840, p. 3; 21/05/1845, p. 6); O Doutrinário (26/05/1848, p. 4).
} 


\section{Uma leitura dos corpos escravos através dos anúncios de fugas (Sécullo XIX)}

"corpo e estatura regular" e "uma cicatriz no lado direito do pescoço" também era gago. Outro Raimundo, "estatura e corpo regular", tendo "ao pescoço uma cistula", era "um pouco gago". O "molatinho" Nicolau, 14 para 15 anos, com "uma cicatriz na face e outra na testa", também era "um pouco gago". Já certo "molatinho", 10 para 12 anos, que "quando anda parece coixo", gaguejava "alguma coisa quando falla". ${ }^{19}$ Ainda que a gagueira seja uma disfunção que possa ser causada por fator genético, existem no seu desenvolvimento fatores sociais e psicológicos, que bem podiam ser acentuados pela condição cativa.

As condições de vida cotidiana dos trabalhadores escravos, no que dizia respeito à saúde bucal se traduzia na perda das dentaduras, por falta de cuidados e ausência de dieta alimentar rica em proteínas. Fazendo com que os cativos fossem pessoas desdentadas, tais como Joaquim com todos os “dentes podres". Senhorinha, "gorda, boa estatura e olhos muito vivos", também era "desdentada na frente". Joaquina, por sua vez, não tinha "tres dentes da frente". Pedro, com "falta de um dedo em hum dos pés [e] cicatriz de um golpe na barriga”, também mostrava “falta de alguns dentes". João Marajó, com "cara redonda com alguns siganes de bixiga”, também se fazia reconhecer pela "falta de dentes superiores na frente". ${ }^{20}$ È verdade que a perda dos dentes não era condição exclusiva da saúde bucal dos cativos, sendo presente em pessoas livres, mas, dentes podres ou a falta deles eram sinais ou marcas nos corpos cativos que ajudavam seu reconhecimento.

Enfim, as informações contidas nos anúncios sobre diversas patologias, das quais dei uma breve notícia, já tem sido objeto de estudos na área da história da saúde, constituindo um campo ainda novo de investigação social dentro da historiografia da escravidão brasileira. ${ }^{21}$

\section{CORPO E IMAGINÁRIO}

Por natureza, os anúncios de fuga são imagens senhoriais sobre os escravos. São retratos falados, ainda que impressos, dos corpos cativos que se desejam reconhecidos. São, portanto, parte constitutiva e constituinte do imaginário social da escravidão. Nos anúncios, os escravos aparecem descritos como o outro, a humanidade que se escraviza ou pode ser escrava. Representações dos cativos e sobre os cativos. Retratos de trabalhadores escravos, retratos de corpos e almas. Assim, os anúncios de fuga são importantes testemunhos sociais sobre o ser escravo,

19 Ver Referências nos Jornais: O Planeta (23/06/1850, p. 3); O Velho Brado do Amazonas (28/05/, p. 6); O Planeta (29/09/1851, p. 4); O Publicador Paraense (18/09/1851, p. 4); O Planeta (31/05/1851, p.4; 31/05/1851, p. 4); Treze de Maio $(19 / 08 / 1840$, p. 4).

${ }^{20}$ Ver Referências nos Jornais: O Planeta (4/11/1852, p. 4; 11/04/1850, p 4); O Velho Brado do Amazonas (28/03/1851, p. 4); O Doutrinário (7/10/1848, p. 4); Treze de Maio (7/11/1840, p 2). Ver outros exemplos em: Treze de Maio (11/12/1840, p. 2; 30/11/1844, p. 3; 13/08/1845, p. 3; 17/12/1845, p. 4; 3/06/1846, p. 4); O Publicador Paraense (4/05/1850, p. 4; 18/10/1852, p. 8); O Doutrinário (8//04/1848, p. 4; 16/04/1849, p. 4); O Planeta (30/03/1853 p. 4); O Publicador Paraense (24/01/1851, p. 4; 16/11/1852, p. 4).

${ }^{21}$ Sobre a relação entre corpo e saúde, corpo e dor, corpo e doença, bem como a história do rosto e do sorriso, incluindo aí a saúde bucal e os dentes, ver, por exemplo: Lieberman (2015); Courtine (2013); Courtine; Haroche (2016); Vigarello (2020); Corbin (2020); Courtine (2020); Le Breton (2013; 2016; 2019A; 2019A); Matos (2019). Sobre história da saúde escrava, para além dos textos já citados, ver, por exemplo, Viana $(2013 ; 2014 ; 2018)$. 


\section{Uma leitura dos corpos escravos através dos anúncios de fugas (Século XIX)}

permitindo perceber pelo não dito, ou não enunciado de forma explícita, algo a princípio paradoxal, a condição protagonista do escravo. Não necessariamente pelo fato de que se trata do anúncio de uma fuga. Mas, pelo quê os anunciantes podem dizer sobre os fugitivos, para além de uma série de dados e descrições físicas, quando informam acerca de seus corpos os aspectos gestuais ou culturais, seus comportamentos ou atitudes, enfim as idiossincrasias dos cativos.

Os anúncios de fugas são testemunhos sociais do protagonismo escravo em suas dissimulações diante o domínio senhorial. O pedreiro Manoel, 26 anos, "baixo", "cabellos pouco corridos", que "em uma das costas da mão tem uma costura ou espécie de berruga ao comprido" e "costuma ter o cabello do bigode crescidos, o que o poderá fazer passar por dezertor de primeira linha", segundo seu senhor, "quando falla parece muito humilde". Humilde ou não, quando fugiu "levou toda a ferramenta de seu ofício". Serafim, 20 a 25 anos, "principiando a serrar a barba", "rosto comprido", "nariz regular, achatado na ponta", "um tanto bambo do corpo", dizia o anunciante que "a primeira vista indica ser simples ou tolo do que não têm nada", sendo na visão senhorial "preguiçoso". Serafim intitulando-se forro, dizia "andar com licença de seu senhor". Raymunda, na visão de seu senhor, era "muita amiga de brincar" e "mente por demais", dizendo "às vezes que é forra" e como tal dizia que trabalhou na casa de seu senhor "para tirar qualquer dúvida sobre si”. Severo, que tinha dentes perfeitos, usava de "nomes supostos, ora Simplício, ora Domingos e outros conforme a localidade por onde tem sido aceitado, illudindo ser livre ou liberto".22

A cativa Maria era retratada como "muito feiticeira e mentirosa por condição". Já Marcellino, que falava devagar para se fazer entender e cruzava os braços quando falava com pessoa branca, fazendo gesto de submissão, apesar de seu gestual já era visto como rebelde pelo senhor. Por fim, um último exemplo: Elesbão que, aleijado de uma perna em consequiência de um tiro, andando com a ajuda de uma bengala, mudava seu nome para José Vallerio, se dizendo inválido da pátria, porque sendo prognóstico quem o ouvia falar acerca da Guerra do Paraguai o tomava "facilmente por um voluntário inválido ao serviço da pátria". ${ }^{23}$

Os anúncios de fuga, portanto, são reveladores de determinados gestuais ou práticas comportamentais dos cativos. Tal como Elesbão, outros eram prognósticos, sendo o caso de José, "muito esperto e fallador". Outros de nome José também foram retratados como "bem falante" ou que "falla muito", ainda que houvesse certo José considerado "pouco falante". ${ }^{24}$ Enfim, muitos eram caracterizados como falantes. Alguns deles sendo "desembaraçado" como Jerônimo, ou "muito desembaraçado e esperto" tipo Joaquim, havendo quem fosse "bastante curioso", neste caso Mathias. João, além de "muito risonho", era "muito conversista, de forma que

\footnotetext{
${ }^{22}$ Ver as referências na nota seguinte.

${ }^{23}$ Ver referências nos seguintes jornais: O Planeta (12/12/1851, p. 3); Treze de Maio (26/02/1845, p. 4); Diário do Gram-Pará (14/09/1867, p. $4 ; 30 / 10 / 1867$, p. 3; 19/12/1867, p. 3; 17/09/1867, p. 3; 30/08/1868, p. 3.).

${ }^{24}$ Ver referências nos seguintes jornais: O Velho Brado do Amazonas (25/09/1852, p. 2);

O Treze de Maio (5/05/1846), p. 4; Diário do Gram-Pará (11/05/1872, p. 3; 3/01/1872, p. 4.).
} 


\section{Uma leitura dos corpos escravos através dos anúncios de fugas (Sécullo XIX)}

quando conversa contando algum caso ou anedocta, mais se applaude elle a si próprio, do que o ouve". Marianna, por sua vez era de falar pouco, mas "muito espivitada". Já no caso de Úrsula, "as veias do pescoço, quando se zanga, ou altera-se, engrossão-lhe, e tremem, assim como os beiços". ${ }^{25}$

Os cuidados com o corpo e o vestuário também aparecem nos anúncios aqui tratados, revelando certas vaidades por parte dos cativos, apesar de sua sujeição social, apesar da escravidão, afinal não deixavam de serem sujeitos, que em sua resiliência não haviam deixado de viver. O vaqueiro africano Pedro usava "brinquinho de ouro na orelha", sendo "muito vivo no olhar". O carafuz Matheus "bem fallante", que "anda regularmente", levou em sua fuga "calça e camisa de algodão", costumando "trazer ao pescoço um rosário de contas vermelhas e azues". Boaventura, com “cicatrizes d'azorrague antiga nas pás", ainda que tivesse "alguns sinais de bixos nos pés, e estes abertos para fora", fazia uso de trunfa de cabelo, isto é, certo toucado antigo ou turbante. ${ }^{26}$ Para além das vaidades no jeito de ser e de se vestir, o uso do rosário e de turbante bem podia ser indicativo de vivências religiosas associadas, por exemplo, ao candomblé. No caso do rosário de contas vermelhas e azuis, por exemplo, "deveria ser sim, de 'proteção' especialmente nas circunstâncias de fuga de um escravo”, segundo nos disse a professora Anaíza Vergolino, ${ }^{27}$ contando-nos ainda que “A cor AZUL tem vínculo com o orixá OGUM que tem os atributos de um orixá guerreiro, de defesa por ser um 'senhor dos caminhos' (veja aí o simbolismo ligado aquele que foge)”. Dizendo, ainda, que: “A cor VERMELHA, no caso intercalando a azul tem relação com o orixá EXU que reina nas encruzilhadas, por extensão também nos caminhos (novamente o simbolismo)"; completando: "Agora, a junção do par AZUL/VERMELHO remete a uma modalidade do orixá Ogum que no Candomblé é conhecido como OGUM XOROQUÊ; é uma espécie de Ogum 'cruzado' com Exu; o que significa a somatória de seus atributos de poder com os poderes de Exu". Concluindo então que: "Esta modalidade de Ogum assim conhecida no Candomblé, na Umbanda nacional e na tradição Mina-Nagô, de Belém, é conhecido como Ogum Megê", ${ }^{28}$

Enfim, no tocante aos cuidados com a aparência, encontramos Balthazar, oficial de carpina, com "falla um pouco descançado", "estatura regular", "pernas um pouco arqueadas”, que usava "bigode e pera (também chamada de barba real, ou pera real, ou seja, bigode ancorado por uma faixa de barba vertical contornando o queixo) e cabelleira grande" e que, segundo o senhor, gostava "muito de andar penteado". O carafuz Fidelis usava bigode. Francisco Alfaiate, que pisava "como se tivesse os pez cheio de bixos" e tinha "sicatrizes de ser surrado", "estatura ordinária", "bem nutrido" e "alguns cabellos brancos", fazia uso de suíças (barba que se usa nas partes

\footnotetext{
${ }^{25}$ Ver referências nos seguintes jornais: Treze de Maio (16/10/1844, p. 4); O Planeta (7/08/1852, p. 4); Treze de Maio (30/11/1844, p. 4); Diário do Gram-Pará (25/11/1868, p. 4); Treze de Maio (5/06/1845, p. 4); O Planeta (6/09/1849, p. 4.).

${ }^{26}$ Ver referências nos seguintes jornais: O Publicador Paraense (21/02/1850, p. 4.); Jornal do Pará (24/09/1868, p. 3.); O Publicador Paraense (31/12/1850, p. 4).

${ }^{27}$ Informação prestada em forma de texto pela professora e antropóloga Anaíza Vergolino em conversa via WhatSapp com o autor, em 17 de outubro de 2020. A quem agradecemos a informação prestada gentilmente, após inclusive ter a Professora Vergolino trocado ideias com o Pai Musa.

${ }^{28}$ Ver a nota 26.
} 
laterais do rosto), enquanto outros cativos faziam uso da barba, alguns deles trazendo-a bem aparada e cuidada. Era o caso de Manoel que barbado, "sempre as trazia feita". Manoel Ramos Doce, 25 anos, "cheio de corpo", "alto", "nariz chato", "muito bem falante", com "muitos sinais de vergalho nas costas, e no assento", e que, dizia o anunciante, fumava e mascava tabaco e gostava "sumamente de pinga", tinha "alguma barba, às vezes raspada, outras crescida". Salvador, "bem falante" e tocador de viola, também fazia a barba. Pedro, que trocava o nome para Antônio, já usava de passa-piolho, isto é, corte ou talhe de barba, de uma orelha à outra, por sob o queixo. Manoel Antônio, barbado, usava meia suíça, tendo "dentes aguçados". Alguns eram descritos com os dentes limados ou apontados, tal qual o já citado Pedro que, "muito prosista" e cantador de "modinhas" tinha os "dentes claros e apontados". Sendo o caso de Olímpio também, dentre outros. ${ }^{29}$

Havendo cativos vaidosos ou que cuidavam de si, havia também cativas, tais como Francisca que usava “cabello crescido e sempre penteado". Ou Virginia com "dentes apontados"; não sendo diferente Alexandrina, 24 anos, "mulata acafuzada", falante, "bem parecida", que tinha os cabelos grandes e costumava andar de vestido, "levando com ela algumas roupas, obras d'ouro e cascos". A preta Ana Isabel, 30 a 40 anos, com "estatura regular" e "falla descansada e fina" tinha "a ponta de uma orelha rasgada", talvez sinal que usava argolas. Joaquina, 26 a 27 anos, "espigada", com "muita semelhança da mãe na fizionomia, mas bem feita e nutrida", com os olhos quase semelhantes aos da mãe, quando andava pela rua "parece que vai aos saltos", com "as cadeiras um pouco elevadas para fora", sendo "muito viva e esperta", mas "séria, carrega muito o rosto", e que andava sempre de vestido desde pequena. Maria Luiza, 18 a 20 anos, "cabello curto" e "bastante encaracolado", tinha um "semblante risonho". Por sua vez, Apolinária, 17 anos, "cabelo anelado e curto", por conta que estava de luto devia "estar com vestido de panno preto" em sua fuga, demonstrando então que a condição escrava não tinha sido capaz de tolher a expressão de sentimentos, inclusive a alegria ou a tristeza. ${ }^{30}$

\section{RELAÇÃO ENTRE CORPO E IDENTIDADE}

A partir dos anúncios de fugas se percebe o uso de tatuagens e/ou escarificações pelos cativos, ainda que viessem a se tornar sinais de identificação dos fugitivos, o que, no entanto, nos remetem à relação entre marcações corporais e identidade visual, para além daquilo que já foi dito até aqui. No caso de cativos africanos, eles traziam em seus corpos marcas identitárias de suas origens sociais e étnicas. Era o caso de Luiza "com bordados da sua nação feitos à ferro, nos braços e em outras partes do corpo", trazendo "a carapinha entrançada à moda do

\footnotetext{
${ }^{29}$ Ver as referências nos jornais: Diário do Gram-Pará (14/03/1871, p. 4; 17/12/1867, p. 4.); Treze de Maio (7/06/1845, p. 4); Diário do Gram-Pará (10/12/1868, p. 4); O Publicador Paraense (26/11/1850, p. 4); Ėpocha (9/06/1859, p. 4); Diário do GramPará (29/04/1868, p. 3); O Doutrinário (13/05/1848, p. 4) Diário do Gram-Pará (9/06/1867, p. 4); O Velho Brado do Amazonas (4/01/1851, p. 4.).

${ }^{30}$ Ver as referências nos jornais: Diário do Gram-Pará (9/06/1867, p. 4); Gazeta Official (14/06/1859, p. 4); O Publicador Paraense (19/07/1851, p. 4; 21/11/1849, p. 4); O Planeta (6/09/1849, p. 4); O Publicador Paraense (21/11/1849, p. 4); Diário do Gram-Pará (6/04/1869, p. 4).
} 
maranhão, onde já esteve em outro tempo". Jezuína, oriunda de Moçambique, trazia "marcas na testa"; Maria, vinda de Angola, era "carimbada na testa com marca de sua terra"; Joaquina trazia "um chadrêz à moda da sua terra na boca do estomâgo". Raimundo, por sua vez, tinha "em ambas as fontes signaes próprios da sua terra"; outro nascido na costa d'África tinha a "cara alanhada". ${ }^{31}$

O falar português com sotaque também configurava possibilidade de identificar os fugitivos africanos, ainda mais quando o percentual de africanos diminuíra significativamente entre os cativos a partir da segunda metade do século XIX. Daí que o senhor de Felícia dizia que, embora natural da África, a fugida se dizia crioula, isto é nascida no Brasil, apropriando-se de uma nova identidade, isto porque "criada desde pequena em Macapá, relatava o anunciante, não mostra[va] pela falla ser de fóra”, ou seja, africana. No caso de Luiza, já citada há pouco, demonstrava ser natural da África "pela fala atrapalhada que tem" (O PUBLICADOR PARAENSE, 26/11/1850, p. 4).

Mas, não só as marcações identitárias da condição africana são possíveis serem vistas nos corpos cativos. Tatuagens também podem remeter ao imaginário e mentalidades dos escravos que traziam e traduziam em seus corpos suas visões de mundo, de si mesmos e de pertencimento social. Assim sendo, o pedreiro Amaro trazia "as iniciais A. A. O. em um dos braços e no outro uma espécie de águia tudo feito a tinta de genipapu". O cafuz Roque era outro que trazia impresso no corpo tatuagem: "no braço esquerdo uma pintura feita com agulha e tinta de carvã representando um vaso com uma planta de três hastes". Manoel, por sua vez, tinha em "hum dos braços pintada de azul a corôa imperial, e em outro huns algarismos também da mesma côr". Benedicto, por sua vez, tinha "os braços pintados com uma sereia"; ao passo que Izidro tinha "uma estrella ou cruz no braço, feita a tinta de jenipapo". 32

\section{CONCLUSÕES}

Outras tantas coisas poderiam ser ditas ou, já enunciadas aqui, serem aprofundadas a partir e através das análises dos anúncios de fugas escravas, mas chega hora de concluir. Mas, concluindo, enfatizo apenas que a partir dos anúncios de fugas podemos conhecer um pouco mais sobre o escravo que fugia, tais como sua capacidade de resiliência; sua personalidade e temperamentos; reveladores de alguns dos seus jeitos de ser e de sentir as coisas, enfim sua condição humana. Assim sendo, lhes deixo na companhia de Manoel José, cujos "olhos grandes e bem salientes, quando falla fita-os na pessoa", revelando certa altivez apesar da escravidão, apesar de ser escravo (DIÁRIO DO GRAM-PARÁ, 17/09/1867, p. 4).

\footnotetext{
${ }^{31}$ Ver referências nos jornais: O Publicador Paraense (26/11/1850, p. 4); Treze de Maio (28/10/1843, p. 4); O Publicador Paraense (26/11/1850, p. 4); Treze de Maio (24/05/1844, p. 4); O Publicador Paraense (8/03/1850, p. 4); Treze de Maio (21/05/1845, p. $4 ; 28 / 04 / 1846$, p. 4.).

32 Ver referências nos jornais: Diário do Gram-Pará (5/12/1867, p. 4); O Doutrinário (15/07/1848, p. 4); Treze de Maio (14/05/1845, p. 4); Gazeta Official (15/06/1859, p. 4); Jornal do Pará (6/03/1870, p. 3.).
} 


\section{REFERÊNCIAS BIBLIOGRÁFICAS}

ABREU, Tenner Inauhiny de. Marcas da escravidão: Condições físicas e saúde dos trabalhadores escravos nos anúncios de fuga nos Periódicos na Província do Amazonas. Somanlu, Manaus, ano 14, n. 1, jan./jun. 2014. Disponível em: https://www.periodicos.ufam.edu.br/index.php/somanlu/article/view/3967. Acesso em: 20/03/2018.

AILVA, Régia A. da. Escravidão e resistência no Maranhão: anúncios e fugas escravas no século XIX. Revista de História UEG, Goiânia, v. 3, n. 2, pp. 30-51, jul./dez 2014. Disponível em: https://www.revista.ueg.br/index.php/revistahistoria/article/view/2143. Acesso em: 20/03/2018

ALKMIM, Tania. A fala como marca: escravos nos anúncios de Gilberto Freire. Scripta, Belo Horizonte, v. 9, n. 18, pp. 221-229. $1^{\circ}$ semestre de 2006. Disponível em: http://periodicos.pucminas.br/index.php/scripta/ article/view/12603. Acesso em: 20/03/2018.

AMANTINO, Márcia. As condições físicas e de saúde dos escravos fugitivos anunciados no Jornal do Commercio (RJ) em 1850. História, Ciências, Saúde - Manguinhos, Rio de Janeiro, v. 14, pp. 1377-1399. out./dez. 2007. Disponível em: https://www.scielo.br/scielo.php?pid=S0104-59702007000400015\&script =sci_abstract\&tlng=pt . Acesso em: 20/03/2018.

AMANTINO, Márcia. Os escravos fugitivos em Minas Gerais e os anúncios do Jornal "O Universal”- 1825 a 1832. Locus, Juiz de Fora-MG, v. 12, n. 2, pp. 59-74, 2006. Disponível em: https://periodicos.ufjf.br/index.php/locus/article/view/20642. Acesso em: 20/03/2018.

ARASSE, Daniel (Org.). História do corpo. Da Renascença às luzes. Vol. 1. Rio de Janeiro: Vozes, 2011.

BEZERRA NETO, José Maia. Fugindo, sempre fugindo. Escravidão, fugas escravas e fugitivos no Grão-Pará (1840-1888). 2000, 264 páginas, Dissertação (Programa de Pós-Graduação em História). Unicamp, São Paulo, 2000.

BRANDÃO, Helena Nagamine. Escravos em anúncios de jornais brasileiros do século XIX: discurso e ideologia. Estudos Linguísticos XXXIII, Campinas-SP, pp. 694-700. 2004. Disponível em: http://www.gel.org.br/4publica-estudos2004-comunics/o_silencio_interacao.pdf. Acesso em: 20/03/2018.

CÂMARA, Juliana de Cássia. Escravos em fuga: histórias de escravidão e "liberdade" no Paraná provincial (18541888). 2013, 73 páginas. Monografia (Graduação em História). UFPR, Curitiba, Departamento de História. 2013. Disponível em: http://www.humanas.ufpr.br/portal/historia/files/2013/12/TCC-JULIANA-CAMARAFINAL.pdf. Acesso em: 20/03/2018.

CARDOSO, Fernando Henrique. Capitalismo e escravidão no Brasil Meridional. O negro na sociedade escravocrata do Rio Grande do Sul. Rio de Janeiro: Paz e Terra, 1977.

CECCARELLI, Paulo Roberto. Uma breve história do corpo. In: LANGE, Elaine Soares Neve.; TARDIVO, Leila Salomão La Plata C. (Orgs.). Corpo, alteridade e sintoma: diversidade e compreensão. São Paulo: Vetor, 2011, pp. 15-34.

CORBIN, Alain (Org.). História do corpo: da revolução à grande guerra. v. 2. Rio de Janeiro: Vozes, 2011. 


\section{Imagens escravas nas visões senhoriais: Uma leitura dos corpos escravos através dos anúncios de fugas (Sécullo XIX)}

CORBIN, Alain (Org.). História das emoções: das luzes até o final do século XIX. v. 2. Rio de Janeiro: Vozes, 2020.

COSTA, Emília Viotti da. Da senzala à colônia. São Paulo: Brasiliense, 1989.

COURTINE, Jean-Jacques (Org.). História do corpo: as mutações do olhar. O século XX. v. 3. Rio de Janeiro: Vozes, 2011.

COURTINE, Jean-Jacques. Decifrar o corpo: pensar com Foucault. Rio de Janeiro: Vozes, 2013.

COURTINE, Jean-Jacques; HAROCHE, Claudine. História do rosto: exprimir e calar as emoções (Do século 16 ao começo do século 19). Rio de Janeiro: Vozes, 2016.

COURTINE, Jean-Jacques (Org.). História das emoções. Do final do século XIX até hoje. v. 3. Rio de Janeiro: Vozes, 2020.

DEL PRIORI, Mary. Dossiê: a história do corpo. Anais do Museu Paulista, São Paulo, v. 3, pp.9-26. jan./dez.1995. Disponível em: https://www.scielo.br/scielo.php?script=sci_nlinks\&ref=000045\&pid=S01014714199700010000700010\&lng=en. Acesso em: 20/08/2019.

DEL PRIORI, Mary; AMANTINO, Márcia (Orgs.). História do corpo no Brasil. São Paulo: Editora Unesp, 2011.

DIÁRIO DO GRAM-PÁRÁ, 9/06/1867, p. 4; 17/07/1867, p.3; 14/09/1867, p. 4; 17/09/1867, p. 3; 17/09/1867, p. 4; 30/10/1867, p. 3; 9/11/ 1867 , p. 4; 5/12/1867, p. 4; 17/12/1867, p. 4; 19/12/1867, p. 3; 29/04/1868, p. 3; $30 / 08 / 1868$, p. $3 ; 25 / 11 / 1868$, p. $4 ; 10 / 12 / 1868$, p. $4 ; 6 / 04 / 1869$, p. $4 ; 14 / 03 / 1871$, p. $4 ; 3 / 01 / 1872$, p. $4 ; 11 / 05 / 1872$, p. 3

DIAS, Eliane Cristina Jorge. As condições físicas e de saúde dos escravizados nos anúncios de jornais da Paraíba Oitocentista (1850-1888). Temporalidades, Belo Horizonte, vol. 3, n. 2, , pp. 98-112, ag./dez. 2011. Disponível em: https://periodicos.ufmg.br/index.php/temporalidades/article/download/5434/3366/. Acesso em: 20/08/2019.

ÉPOCHA, 9/06/1859, p. 4.

FERNANDES, Florestan. A integração do negro na sociedade de classes. São Paulo: Ática, 1978. Hucitec; Curitiba, Scientia et Labor, 1988.

FERRARI, A. O gesto de fuga como ato simbólico. Temas e matizes. Cascável-PR, n. 2, pp. 74-78. 2001.

FERRARI, Ana Josefina. A voz do dono: uma análise das descrições feitas nos anúncios de jornal dos escravos fugidos. Campinas: Editora Pontes, 2010.

FERRARI, Ana Josefina. Fuga e resistência: o caso das fugas dos escravos na cidade de Campinas entre 1870 e 1880. Revista Conexão Letras, Porto Alegre, v. 1, n. 1, sem numeração de páginas, 2015. Disponível em: https://seer.ufrgs.br/conexaoletras/article/view/55662. Acesso em: 20/08/2019.

FERREIRA, Heloísa Souza. O olhar do estabelecido: A imagem do escravo produzida pelos senhores nos anúncios de jornais do Espírito Santo (1849-1888). I SEMINÁRIO NACIONAL DA PÓS-GRADUAÇÃO EM CIÊNCIAS SOCIAIS, 2011. Vitória-ES, Anais [...].- UFES, v. $1, \quad$ n. 1 Disponível em: https://www.periodicos.ufes.br/snpgcs/issue/view/131. Acesso em: 20/08/2019. 


\section{Imagens escravas nas visões senhoriais: Uma leitura dos corpos escravos através dos anúncios de fugas (Século XIX)}

FREITAS, Décio. Escravismo brasileiro. Porto Alegre, Mercado Aberto, 1982.

FREYRE, Gilberto. O escravo nos anúncios de jornais brasileiros do século XIX. São Paulo, Ed. Nacional; Recife: Instituto Joaquim Nabuco de Pesquisas Sociais, 1979.

GAZETA OFFICIAL, 14/06/1859, p. 4; 15/06/1859, p. 4.

GOMES, Flávio dos Santos. Jogando a rede, revendo malhas: fugas e fugitivos no Brasil escravista. Tempo, Rio de Janeiro, v. 1, pp 67-93. 1996.

GORENDER, Jacob. A escravidão reabilitada. São Paulo: Ática, 1990.

GOULART, José Alípio. Da fuga ao suicídio: aspectos da rebeldia do escravo no Brasil. Rio de Janeiro, Editora Conquista, 1972.

GRAF, Elisa de Campos. Imprensa periódica e escravidão no Paraná. Curitiba: Secretaria de Estado de cultura e esporte, 1981.

GUIMARÃES, Carlos Magno. A negação da ordem escravista: quilombos em Minas Gerais no século XVIII. São Paulo, Ícone, 1988.

IANNI, Octávio. As metamorfoses do escravo: apogeu e crise da escravatura no Brasil Meridional. São Paulo: Hucitec; Curitiba: Scientia e Labor, 1988.

JESUS, Antonio Marcos Cardoso de. O corpo escravo: suas condições físicas e de saúde nos anúncios de fuga do jornal A Matutina Meiapontense (1830-1833). In: CONGRESSO INTERNACIONAL DE HISTÓRIA, 5, 2016. Jataí-GO, Anais [...]. Disponível em: www.congressohistoriajatai.org/2016/resources/anais/6/147614268 6. Acesso em: 20/09/2019.

JORNAL DO PARÁ,15/09/1868, P. 3; 24/09/1868, p. 3; 6/03/1870, p. 3.

LARA, Sílvia. Campos da violência: escravos e senhores na Capitânia do Rio de Janeiro, 1750-1808. Rio de Janeiro: Paz e Terra, 1988.

LE BRETON, David. Sociologia do corpo. Rio de Janeiro: Vozes, 2012.

LE BRETON, David. Antropologia da dor. Rio de Janeiro: Vozes, 2013.

LE BRETON, David. Antropologia dos sentidos. Rio de Janeiro: Vozes, 2016.

LE BRETON, David. Antropologia das emoções. Rio de Janeiro: Vozes, 2019a.

LE BRETON, David. Rostos: Ensaio de antropologia. Rio de Janeiro: Vozes, $2019 \mathrm{~b}$.

LIEBERMAN, Daniel. A história do corpo humano: evolução, saúde e doença. Rio de Janeiro: Editora Zahar, 2015.

LUNA, Luís. O negro na luta contra a escravidão, Rio de Janeiro, Leitura, 1968; 
MANEIRA, Regiane. Anúncios de escravos no jornal O Dezenove de Dezembro (Curitiba - 1854) e suas possibilidades de pesquisa. Revista Tempo, Espaço, Linguagem. Irati-PR, v. 5, n. 2, pp. 36-49. Ago. 2014 Disponível em: https://revistas2.uepg.br/index.php/tel/article/view/6628. Acesso em: 15/09/2019.

MATOS, Maria Izilda S. de. Por uma possível história do sorriso. Institucionalização, ações e representação. São Paulo: Editora Hucitec, 2019.

MOTT, Luiz. Os escravos nos anúncios de jornal em Sergipe. In: ENCONTRO NACIONAL DE ESTUDOS POPULACIONAIS, 5, 1986, Águas de São Pedro. Anais [...].. v. 1.

MOTT, Luiz. O escravo nos anúncios de jornal de Sergipe. 1833-1864. In: MOTT, Luis. (Org.). Sergipe colonial e imperial: religião, família, escravidão e sociedade: 1591-1882. São Cristóvão: Editora UFS; Aracaju: Fundação Oviêdo Teixeira, 2008. pp. 95-117.

MOURA, Clóvis. Rebeliões da senzala. São Paulo: Editora Ciências Humanas, 1981.

NEVES, Raphael. Experiências capturadas: a fuga de escravos no Rio de Janeiro. Monografia, 2009, 99 páginas, (Graduação em História). Rio de Janeiro: UFRJ, Rio de Janeiro, 2009. Disponível em: https://www.bn.gov.br/sites/default/files/documentos/producao/pesquisa/experiencias-capturadas-fuga-escravosrio-janeiro/raphael_neves.pdf. Acesso em: 26/08/2020.

O CORREIO DOS POBRES, 22/09/1851, p. 4.

O DOUTRINÁRIO, 8/04/1848, p. 4; 16/04/1849, p. 4; 26 /05/1848, p. 4; 13/05/1848, p. 4; 15/06/1848, p. 4; 15/07/1848, p.4; 7/10/1848, p. 4;

O PLANETA, 6/09/1849, p. 4; 11/04/1850, p. 4; 18/04/1850, p. 4; 23/06/1850, p. 3; 23/07/1850, p. $3 ; 17 / 08 / 1850$, p. $8 ; 31 / 05 / 1851$, p. $4 ; 29 / 09 / 1851$, p. $4 ; 12 / 12 / 1851$, p. $3 ; 20 / 12 / 1849$, p. $4 ; 27 / 03 / 1852$, p. $3 ; 7 / 08 / 1852$, p. 4 ; 4/11/1852, p. $4 ; 30 / 03 / 1853$ p. 4.

O PUBLICADOR PARAENSE, 24/10/1849, p. 4; 21/11/1849, p. 4; 21/02/1850, p. 4; 8/03/1850, p. 4; 4/05/1850, p. $4 ; 26 / 11 / 1850$, p. $4 ; 31 / 12 / 1850$, p. 4; 24/01/1851, p. 4; 19/07/1851, p. 4; 18/09/1851, p.4; 22/10/1851, p. 4; 28/06/1852, p. 4; 18/10/1852, p. 8; 16/11/1852, p. 4.

O VELHO BRADO DO AMAZONAS, 4/01/1851, p. 4; 28/03/1851, p. 4; 26/03/1852, p. 4; 28/05/1852, p. 6; 25/09/1852, p. 2.

PEREIRA, Francinete Poncadilha. A mulher escrava nos anúncios dos jornais de São Luís. In: SIMPÓSIO DE HISTÓRIA DO MARANHÃO OITOCENTISTA, 3, 2013. São Luís, Anais [...]. Disponível em: https://silo.tips/download/a-mulher-escrava-nos-anuncios-dos-jornais-de-sao-luis. Acesso em: 18/10/2020.

QUEIRÓZ, Suely Rubles Reis de. Escravidão negra em São Paulo. Um estudo das tensões provocadas pelo escravismo no século XIX. Rio de Janeiro, José Olympio, 1977.

QUEIRÓZ, Suely Robles Reis de. Escravidão e memória. D.O. Leitura, no 7, pp. 27-29. nov./1999. 
RABELATTO, Martha. Fugas escravas e quilombos na Ilha de Santa Catarina, no séc. XIX. 2006, 153 f., 2006. Dissertação (Mestrado em História). UFSC, Florianópolis, 2006. Disponível em: https://repositorio.ufsc.br/xmlui/handle/123456789/89505 Acesso em: 25/05/2019.

RABELATTO, Martha. O desmantelamento da escravidão, as alforrias e as fugas de escravos na Ilha de Santa Catarina, década de 1880. ENCONTRO ESCRAVIDÃO E LIBERDADE NO BRASIL MERIDIONA, 3, 2007. Florianópolis, Anais [...] UFSC, 2007. Disponível em: http://www.escravidaoeliberdade.com.br/site/ index.php?option=com_content\&view=article\&id=118\&Itemid=63. Acesso em: 25/05/2019.

REIS, Liana Maria. Escravos e abolicionismo na imprensa mineira - 1850/1888. 179 f. Dissertação (Mestrado em História). Belo Horizonte: FAFICH/UFMG, 1993.

RODRIGUES, J. C. O corpo na história. Rio de Janeiro: Editora FIOCRUZ, 1999.

SCHWARCZ, Lilia Moritz. Retrato em branco e negro: jornais, escravos e cidadãos em São Paulo no final do século XIX. São Paulo: Companhia das Letras, 1987.

SILVA, Eduardo. Fugas, revoltas e quilombos: os limites da negociação. In: REIS, João José; SILVA, Eduardo. Negociação e conflito. A resistência negra no Brasil escravista. São Paulo: Companhia das Letras, 1989.

SILVA, Elisa V. Anúncio de fugas no Astro de Minas. ALPHA, Patos de Minas-MG, pp. 34-49. Ago/2010. Disponível em: https://silo.tips/download/a-insubmissao-escrava-os-anuncios-de-fuga-no-astro-de-minas Acesso em: 23/08/2020.

SILVA, José A. da. Escravos nos anúncios de jornais: "Diário de Pernambuco", na segunda metade do século XIX, na década de 1870.In: COLÓQUIO DE HISTÓRIA DA UNICAP, 13 e COLÓQUIO DE HISTÓRIA DO PPGH, 3. 2019. Recife. Anais [...]. Disponível em: http://www.unicap.br/ocs/index.php/coloquiodehistoria/ coloquiodehistoriaxix/paper/download/1452/476. Acesso em: 23/08/2020.

SOUZA, Patricia March de. Visualidade da Escravidão: representações e práticas de vestuário no cotidiano dos escravos na cidade do Rio de Janeiro oitocentista. 2011, 263 folhas. Tese (Doutorado em História Social da Cultura). PUC-RJ, Rio de Janeiro, 2011. Disponível em: https://www.maxwell.vrac.pucrio.br/colecao.php?strSecao=resultado\&nrSeq=17541@1. Acesso em: 23/08/2020.

SOTT, Santierre Luis Krewer. Representações de escravos na seção de anúncios do jornal A Imprensa de Cuyabá. In: ENCONTRO REGIONAL DE HISTÓRIA DA ANPUH-MS, HISTÓRIA E DEMOCRACIA: POSSIBILIDADES DO SABER HISTÓRICO, 13, 2016. Coxim-MS. Anais [...]. Disponível em: http://www.encontro2016.ms.anpuh.org/resources/anais/47/1477410059_ARQUIVO_REPRESENTACOESDE ESCRAVOSNASECAODEANUNCIOS.pdf. Acesso em: 23/08/2020.

TREZE DE MAIO, 15/07/1840, p. 4; 15/08/1840, p. 4; 19/08/1840, p. 4; 29/08/1840, p. 3; 7/11/1840, p 2; $11 / 12 / 1840$, p. $2 ; 28 / 10 / 1843$, p. $4 ; 14 / 05 / 1844$, p. $4 ; 24 / 05 / 1844$, p. $4 ; 25 / 05 / 1844$, p. $3 ; 16 / 10 / 1844$, p. 4 ; $30 / 11 / 1844$, p. $3 ; 30 / 11 / 1844$, p. $4 ; 22 / 01 / 1845$, pp. $3-4 ; 12 / 02 / 1845$, p. $4 ; 26 / 02 / 1845$, p. $4 ; 23 / 04 / 1845$, p. 4 ; $14 / 05 / 1845$, p. $4 ; 21 / 05 / 1845$, p. $4 ; 21 / 05 / 1845$, p. $6 ; 5 / 06 / 1845$, p. $4 ; 7 / 06 / 1845$, p. $3 ; 7 / 06 / 1845$, p. $4 ; 13 / 08 / 1845$, p. $3 ; 12 / 11 / 1845$, p. $4 ; 17 / 12 / 1845$, p. $4 ; 21 / 02 / 1846$, p. $4 ; 28 / 03 / 1846$, p. $3 ; 28 / 04 / 1846$, p. $4 ; 5 / 05 / 1846$, p. 4 ; 3/06/1846, p. 4; 19/06/1846, p. 4; 13/05/1854, p. 4; 9/06/1855, p. 4.

TRUONG, Nicolas; LE GOFF, Jacques. Uma história do corpo na Idade Média. Rio de Janeiro: Civilização Brasileira, 2006. 


\section{Uma leitura dos corpos escravos através dos anúncios de fugas (Sécullo XIX)}

VIANA, Iamara da Silva. Corpo escravizado: discurso médico sobre anatomia, e cura no Rio de Janeiro do Oitocentos. ENCONTRO ESCRAVIDÃO E LIBERDADE NO BRASIL MERIDIONAL, 6, 2013. Florianópolis, Anais [...]. UFSC, 2013. Disponível em: http://www.escravidaoeliberdade.com.br/site/images/ Textos.6/iamarasilvaviana.pdf Acesso em: 23/08/2020.

VIANA, Iamara. da Silva. Corpo escravizado e discurso médico: para além da anatomia (1830-1850). Revista de História Comparada, Rio de Janeiro, v. 12, n. 1, pp. 172-202, 2018, Disponível em: https://revistas.ufrj.br/index.php/RevistaHistoriaComparada/article/view/18816. Acesso em: 23/08/2020.

VIANA, I. da S. Corpo escravizado: diferentes olhares e discursos médicos. SEMINÁRIO NACIONAL DE HISTÓRIA DA CIÊNCIA E DA TECNOLOGIA. 14, 2014. Belo Horizonte, Anais [...]. UFMG, 2014. Disponível em: http://www.sbhc.org.br/resources/download/1422884477_ARQUIVO_IamaradaSilvaViana.pdf. Acesso em: 23/08/2020.

VIGARELLO, Georges. Sentimento de si: História da percepção do corpo - Séculos XVI-XX. Rio de Janeiro: Editora Vozes, 2016.

VIGARELLO, Georges. A história e os modelos do corpo. Pro-Posições, Campinas-SP, v. 14, n. 2 (41), pp. 2129. maio/ago, 2003, Disponível em: https://periodicos.sbu.unicamp.br/ojs/index.php/proposic/article/view/ 8643881 Acesso em: 23/08/2020.

VIGARELlO, Georges (Org.). História das emoções. Da Antiguidade às Luzes. v. 1. Rio de Janeiro: Vozes, 2020.

Texto recebido em: 07/11/2020

Texto aprovado em: $21 / 11 / 2020$ 